Article

\title{
Employment Returns to Tertiary Education for Immigrants in Western Europe: Cross-Country Differences Before and After the Economic Crisis
}

\author{
Raffaele Guetto \\ Department of Sociology and Social Research, University of Milano-Bicocca, 20126 Milan, Italy; \\ E-Mail: raffaele.guetto@unimib.it
}

Submitted: 27 February 2018 | Accepted: 15 May 2018 | Published: 30 July 2018

\begin{abstract}
This article contributes to the literature on the models of immigrants' labour market incorporation in Western Europe by analysing the employment returns to tertiary education for both natives and immigrants. By using yearly EU-LFS data (2005-2013) for a selection of Western European countries, cross-country differences in the employment returns to tertiary education are analysed separately by immigrant status and gender. In Continental Europe, where immigrant-native employment gaps before the crisis were much larger than in Southern Europe, immigrants are found to benefit more from tertiary education, and their returns are also higher than for natives, while the opposite holds in Southern European countries. The same pattern is found irrespective of gender, but cross-country differences are more pronounced among women. The article also documents that the crisis contributed to a cross-country convergence, although limited to men, in the degree of immigrant employment disadvantage, which increased substantially in Southern Europe while remaining unchanged or slightly declining in all other countries. Nevertheless, although immigrant-native employment gaps grew as high as in Continental Europe, immigrant men in Southern Europe are still found to benefit from lower returns to tertiary education than their native counterparts.
\end{abstract}

\section{Keywords}

economic crisis; education; ethnic inequality; labour market; migration; Western Europe

\section{Issue}

This article is part of the issue "The Race for Highly-Skilled Workers", edited by Neli Demireva (University of Essex, UK) and Ivana Fellini (University of Milano Bicocca, Italy).

(C) 2018 by the author; licensee Cogitatio (Lisbon, Portugal). This article is licensed under a Creative Commons Attribution 4.0 International License (CC BY).

\section{Introduction}

The existence of substantial heterogeneity in immigrants' labour market outcomes across Western European countries is well known. More precisely, the literature has outlined the existence of two main models of immigrants' incorporation (Reyneri \& Fullin, 2011a, 2011b). In Central and Northern European countries (referred to as Continental countries henceforth), immigrants face a strong disadvantage compared to their native counterparts in employment probability but are less harshly penalised in terms of job quality. On the other hand, in Southern European countries, immigrants are significantly less harshly penalised in terms of employment opportunities, but they most often hold low-skilled jobs and face high risks of remaining entrapped in the secondary segment of the labour market (Fellini \& Guetto, 2018).

However, the recent economic crisis has reshaped, to some extent, the cross-country pattern of immigrants' penalisation that was outlined above. In Southern European countries, the crisis has been harsher than in other European areas, and its more adverse effects have been on workers who are more weakly attached to the labour market, i.e., those employed in low-skilled occupations and in cyclical industries such as construction and manufacturing (OECD, 2009). Since male immigrants in Southern European countries are largely overrepresented in those occupations, their employment chances sharply deteriorated (Fellini, 2017). This contributed to a convergence in immigrant-native employment gaps between 
the Southern and Continental models, at least among men. The convergence has been limited, however, because immigrants, conditional on remaining employed, have not become more likely to hold high-skilled jobs in Southern Europe (Panichella, 2017)

This article contributes to the literature on the different models of immigrants' labour market incorporation in Western Europe by looking at the cross-country pattern of the employment returns to education. Immigrants are usually found to benefit from lower returns to education compared to natives, both in terms of job quality and wages (Chiswick, 1978; Chiswick \& Miller, 2009; Friedberg, 2000; Kanas \& Van Tubergen, 2009). However, while the limited transferability of the human capital (Chiswick, 1978; Chiswick \& Miller, 2009) and educational credentials (Lancee \& Bol, 2017) acquired in the country of origin may limit access to highly-skilled jobs, the consequences on the employment returns to education are less straightforward and debated. Moreover, the different models of immigrants' labour market incorporation are expected to moderate the extent to which the returns to education differ between immigrants and natives.

By using data from the European Union Labour Force Survey from 2005-2013 (Eurostat, 2013), the article tests whether, how and to what extent the association between the attainment of a tertiary degree and employment status varies by immigrant status and gender in a selection of Western European countries. Based on human capital and credential theories, the employment returns to education should be lower for immigrants compared to natives. However, tertiary education is expected to yield higher returns for immigrants in Continental countries, i.e., where they face greater difficulties in finding a job. In fact, the high demand for highly-skilled jobs in these countries should make the possession of higher education more valuable (Brodmann \& Polavieja, 2011; Kogan, 2006). On the contrary, in Southern Europe, where immigrants have easier access to low-skilled jobs, the employment returns should be lower. In the second step, the way in which employment returns to education have been affected by the crisis is explored, focusing on men only. This article analyses whether the convergence of the Continental and Southern European models of male immigrants' labour market incorporation that has been found in the literature (Panichella, 2017) also concerns employment returns to education. Since male immigrants are generally more affected than natives by negative economic conjunctures (Guzi, Kahanec, \& Kureková, 2015b), the salience of higher education for their labour market attachment is expected to increase in the years following the onset of the crisis. This may hold especially true in Southern Europe, where employment returns for immigrants are expected to be particularly low before the crisis and the latter has hit more severely.

\section{Theoretical Background}

\subsection{Models of Immigrants' Labour Market Incorporation in Western Europe}

Several institutional and labour market characteristics of Western European countries have been posited as influencing the extent to which immigrants are more likely than natives to be not employed or hold a low-skilled job. Starting from institutional settings and focusing on employment probability, a significant emphasis has been placed on the type and degree of labour market regulations in considering the Employment Protection Legislation (EPL), the weight of unions and the level of unemployment benefits. Overall, several studies suggest that a less regulated labour market-i.e., one characterised by lower union density and coverage, looser EPL and less generous unemployment benefits-should reduce the degree of immigrant disadvantage (Causa \& Jean, 2007; Guzi et al., 2015a, 2015b; Huber, 2015; Kogan, 2006, 2007; Markaki, 2014).

The role of the EPL has been highly debated in the literature, however, because theoretical expectations concerning its effects are not straightforward (Reyneri \& Fullin, 2011a; Sá, 2011). The prevailing argument is that immigrants would benefit from looser EPL because lower firing costs would reduce employers' perceived risks associated with hiring immigrant workers who might be "less productive" (Kogan, 2006, 2007). Several studies support this view, although some authors found the strictness of the EPL for permanent and temporary contracts to have opposite effects on immigrants' employment chances (Markaki, 2014; Sá, 2011). As far as the role of unions, since natives are usually over-represented among their members in all Western societies (Visser, 2015), a high rate of union density is expected to increase immigrant disadvantage. The available empirical evidence supports the thesis that the higher the union density is, the worse the immigrants' labour market outcomes are compared to those of natives (Guzi et al., 2015a; Huber, 2015; Markaki, 2014). In fact, the institutional feature of receiving countries that, at least from a theoretical point of view, has been almost unanimously associated with higher ethnic penalties is the generosity of welfare benefits for the unemployed. Empirical evidence suggests that since immigrants tend to have lower reservation wages than natives, high unemployment benefits may be conducive to a "welfare trap", which might increase the immigrant disadvantage in employment opportunities (Causa \& Jean, 2007; Guzi et al., 2015b; Reyneri \& Fullin, 2011a), especially among more vulnerable groups such as refugees and asylum seekers (Hansen \& Lofstrom, 2009).

Shifting to more structural features of receiving societies, the characteristics of labour demand have received significant attention in the literature. Due to the limited transferability of the human capital (Chiswick, 1978) and educational credentials (Lancee \& Bol, 2017) acquired 
abroad, immigrants-especially those newly arrived in the destination country-are generally found to be more likely than comparable natives to hold low-skilled occupations in all Western countries (Heath \& Cheung, 2007). Therefore, it is not surprising that countries with a higher and unsatisfied demand for low-skilled jobs may offer greater employment opportunities for immigrants (Kogan, 2006, 2007; Reyneri \& Fullin, 2011a, 2011b).

By jointly considering the degree of labour market regulations and the demand for low-skilled jobs, Western European countries can be positioned in a twodimensional space as shown in Figure 1. Even if Continental European countries constitute a rather heterogeneous group, they tend to occupy the top-left quadrant of Figure 1, which predicts wide immigrant-native employment gaps. Scandinavian countries represent the most emblematic case because they share a so-called "flexicurity" model of labour market regulation (Madsen, 2006) characterised by moderate levels of EPL, very generous unemployment benefits and high levels of union density (Visser, 2015), together with a relatively high level of qualification of labour demand (Brodmann \& Polavieja, 2011).

Southern European countries share an almost opposite labour market configuration. In these countries, welfare benefits are the least generous in Western Europe (OECD, 2017), and union density levels are lower than the European average (Visser, 2015). Although Southern European labour markets have long been considered the most "rigid" among OECD countries (Nickell, 1997; Siebert, 1997), since the first inflows of the 1980s and 1990s, immigrants have often worked either in the underground economy or in small firms. Thus, immigrants in
Southern European countries have always been included in a specific segment of the labour market where regulation is de facto very low (Reyneri, 1998, 2004). The lack of public services for the care of children and elderly people has generated a demand for (cheap) household and personal services specifically targeting immigrant women (Sciortino, 2004). Furthermore, the prevalence of small firms operating in low human capital intensity sectors has contributed to a high demand for manual workers, usually immigrant men, who are willing to accept more demanding and less protected working conditions (Reyneri \& Fullin, 2011b). Thus, immigrants in Southern Europe are much more likely than natives to be employed in the secondary segment of the labour market characterised by a particularly low degree of unionisation and overall low levels of social protection (Fellini, Ferro, \& Fullin, 2007; Reyneri \& Fullin, 2011b). The high demand for low-skilled jobs combined with the de facto low degree of labour market regulations should produce low levels of immigrant employment disadvantage, as predicted by the bottom-right quadrant of Figure 1. However, the same features of the model of immigrants' labour market incorporation that contributed to their lower disadvantage up to the onset of the Great Recession may be related to worsening immigrant unemployment risks relative to those of natives since then. In fact, the crisis has been particularly harsh in Southern European countries, especially in cyclical industries such as construction and manufacturing (OECD, 2009), where most immigrant men work. Thus, the economic crisis may have increased immigrant-native gaps in Southern Europe to levels closer to those found in Continental Europe, at least among men.

Labour market regulations

(high)

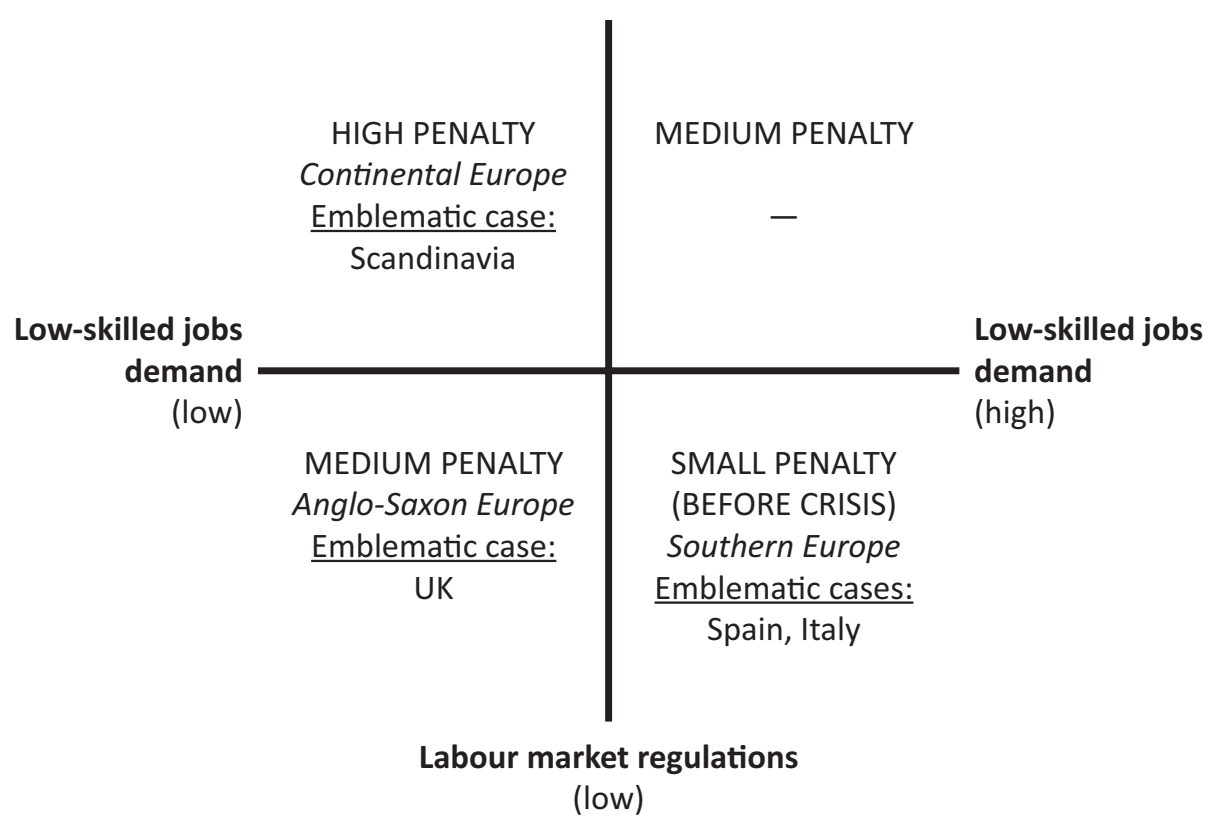

Figure 1. A typology of immigrant employment disadvantage in Western Europe. 
The UK should occupy an intermediate position between the first two groups of countries. On the one hand, UK is well-known as the most unregulated labour market in Western Europe, which should foster better immigrants' employment outcomes. Notwithstanding a labour demand biased towards highly-skilled occupations, which justifies the positioning in the bottom-left quadrant of Figure 1, the immigrant employment disadvantage could be limited by the strictly selective immigration policy that favours the entry of highly-educated workers, especially in the health sector (Hardill \& Macdonald, 2000).

As mentioned in the introduction, the limited available empirical evidence is consistent with the predictions of Figure 1 (Fellini, 2017; Panichella, 2017). That is, in Continental Europe immigrant-native employment gaps were higher than in Southern Europe and the UK before the crisis, but with the onset of the crisis immigrant disadvantage increased substantially in Southern Europe. While additional empirical evidence for a selection of Western European destination countries will be provided in the empirical section, in the following section how the different models of labour market incorporation shape immigrants' employment returns to education will be discussed.

\subsection{What Are the Employment Returns to Tertiary Education for Immigrants across Western European Countries and Economic Conjunctures?}

The bulk of evidence shows that immigrants enjoy lower returns to education compared to natives when access to more skilled occupations and higher wages are considered. However, regarding employment probability, the predictions are more blurred. In what follows, the employment returns to education for immigrants, relative to those for natives, and their differences across countries are deemed to depend not only on the transferability of human capital and educational credentials, but also on the above-mentioned characteristics of the receiving labour markets which influence the degree of immigrant employment disadvantage. Thus, while immigrants should experience lower employment returns to education compared to natives, due to the limited transferability of human capital and educational credentials acquired in the origin country, a high immigrant-native employment gap should make immigrants' possession of higher education more relevant.

In fact, when selecting individuals aged 25 to 54 who are likely to have finished their schooling and are far from retirement age, employment rates among native men tend to be similar and are very high across all Western European countries. In the selection of countries considered in this article and in the period before the crisis (2005-2007), the employment rates of native men ranged from approximately $87 \%$ (Italy) to approximately 93\% (Netherlands), which leaves limited "room" for large employment returns to education. On the other hand, employment rates among immigrant men were significantly lower before the crisis in Continental Europe, which could make higher education more relevant for their employment probability, notwithstanding the lower transferability of the human capital and educational credentials. This should not occur in Southern Europe, where immigrants' employment rates, fostered by the high demand for low-skilled jobs, were as high as those of natives before the crisis (Panichella, 2017). Thus, it can be hypothesised that in Southern European countries before the crisis, the employment returns to tertiary education were higher among native men compared to their immigrant counterparts, due to the limited transferability of immigrants' skills and credentials.

The Western European pattern of immigrant disadvantage changed dramatically after the onset of the crisis. The increasing difficulties for male immigrants in remaining employed in Southern European countries may have increased the relevance of education so that their employment returns to tertiary education, as well as their differences with natives, may have become more similar to those observed among male immigrants in Continental Europe. However, such a reversal of the gap between immigrants and natives in the employment returns to tertiary education cannot be taken for granted. In fact, although to a more limited extent, employment rates decreased substantially also among native men in Southern Europe. For instance, in Spain their employment rate shifted from approximately $87 \%$ in the pre-crisis period to approximately $74 \%$ in the $2011-2013$ period. Thus, increasing employment returns to tertiary education can also be expected from native men in Southern Europe, likely offsetting the concurrent increase among immigrants. In fact, most male immigrants in Southern Europe generally work in manual occupations that are highly sensitive to the economic cycle, regardless of their educational attainment and other personal characteristics (Fellini \& Guetto, 2018). This may have significantly reduced the "protective" function of education. Overall, because of the crisis, male immigrants in Southern Europe may experience a "double penalty" in that their increasing disadvantage in employment probability may go hand in hand with persistently lower employment returns to tertiary education.

When shifting to women, similar results can be expected when comparing cross-country differences in the employment returns to tertiary education for natives and immigrants. As shown in Panichella (2017), the differences in immigrant disadvantage between Continental (and UK) and Southern European countries are larger than among men and those less affected by the crisis. Thus, for immigrant women, even more than for men, the employment returns to tertiary education should be higher in Continental Europe. Regarding the differences between immigrant and native women in the returns, the latter should be positive in Continental and negative in Southern Europe, similarly to the hypothesised figures for men. In fact, the differences between the two 
European areas should be even wider. First, it is wellknown that education is much more important for the labour market participation of women (Steiber \& Haas, 2012), and this may be especially true for immigrant women in Continental Europe, since many of them originate from countries where female employment is not culturally and institutionally promoted, as it will be further discussed. For the same reason, since native women's employment rates are much higher in Continental Europe (and especially in Scandinavia, where they are close to those of men; see Table A1 in Annex), in Southern European countries, education should make a substantial difference for native women's labour market participation (Scherer \& Reyneri, 2008).

Table 1 summarises all the expectations concerning how the employment returns to tertiary education among immigrants and natives should vary across Western European countries before and after the crisis by gender. Among women, the effect of the crisis is not explored since the convergence between the Continental (and UK) and the Southern European models is expected to be much more limited (Panichella, 2017).

Before proceeding with the empirical test of the hypotheses shown in Table 1 , the possibility that differences in the composition of the immigrant populations influence the cross-country patterns outlined above needs to be discussed. Gorodzeisky and Semyonov (2017) found patterns of immigrants' labour market incorporation not to vary much across countries, despite differences in the composition of migration flows. However, their study did not include Southern European countries in the comparison. Three sources of heterogeneity are potentially relevant in determining the higher immigrant disadvantage and the higher returns to education for immigrants in Continental compared to Southern Europe: differences by area of origin, by reason for migration and in the proportion of immigrants who obtained their education in the country of destination.

Immigrants from MENA and sub-Saharan Africa, who have been found to have the lowest employment rates and the highest unemployment rates in Western Europe (Koopmans, 2016; Lancee, 2016), are substantially overrepresented in Continental Europe. Such compositional difference is likely to contribute to both the greater disadvantage and the higher returns to tertiary education for immigrants in Continental countries, especially among women. In fact, the incidence of immigrant women originating from predominantly Muslim countries is much higher in Continental Europe, and, apart from possible discrimination, belonging to Islam and other nonChristian religions, such as Hinduism and Sikhism, has been found to be associated with lower female labour market participation (Guetto \& Fellini, 2017; Heath \& Martin, 2013). This may explain why immigrant-native employment gaps among women are higher in Belgium and France than in Scandinavian countries (see Figure 3 below). Belgium and France indeed have the highest incidence of immigrant women from MENA and sub-Saharan Africa. On the contrary, Southern European countries have received highly feminised migration inflows from Eastern European new EU member, post-Soviet and Latin American countries in the last 20 years, among which the employment rates tend to be higher in all destination countries. ${ }^{1}$ Compositional differences in terms of areas of origin are unlikely to determine the overall crosscountry patterns, however. For instance, approximately $72 \%$ of male non-Western immigrants in France originate from MENA and sub-Saharan Africa, but the immigrantnative employment gaps are substantially lower than in Denmark or Sweden (see Figure 2 below), where the share is approximately $32 \%$ and $45 \%$ respectively. Thus, institutional differences, particularly the generosity of the welfare system and the structure of labour demand, are likely to play the most important role, especially among men.

As far as differences in the reasons for migration, the incidence of refugees is substantially higher in Continental Europe, and especially in Scandinavian countries, a factor which may contribute to both worse immigrants' employment outcomes and a more pronounced educa-

Table 1. Expected intensity of immigrants' employment returns to tertiary education (and differences with natives) across Western European countries.

\begin{tabular}{|c|c|c|c|c|c|c|}
\hline \multicolumn{7}{|c|}{ MEN } \\
\hline & \multicolumn{2}{|c|}{ Continental Europe } & \multicolumn{2}{|r|}{ UK } & \multicolumn{2}{|c|}{ Southern Europe } \\
\hline & Immigrants & Diff. with natives & Immigrants & Diff. with natives & Immigrants & Diff. with natives \\
\hline Before the crisis & +++ & + & ++ & $+/-$ & + & - \\
\hline After the crisis & +++ & + & ++ & $+/-$ & ++ & $+1-$ \\
\hline \multicolumn{7}{|c|}{ WOMEN } \\
\hline & \multicolumn{2}{|c|}{ Continental Europe + UK } & \multicolumn{2}{|c|}{ Southern Europe } & & \\
\hline & Immigrants & Diff. with natives & Immigrants & Diff. with natives & & \\
\hline & ++++ & ++ & + & - & & \\
\hline
\end{tabular}

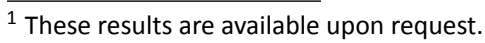


tional gradient in employment (Luik, Emilsson, \& Bevelander, 2016). On the contrary, refugees have always represented a negligible proportion of the immigrant populations in Southern Europe, at least before the recent refugee crisis. Finally, in Southern European countries the percentage of immigrants obtaining their highest level of education in the destination country has been estimated to be particularly small (Fellini \& Guetto, 2018), which could contribute to the lower immigrants' returns to education through lower transferability of human capital and educational credentials. Unfortunately, the data used in this article do not contain information concerning immigrants' reason for migration and place where the highest level of education has been obtained.

\section{Data and Methods}

For the analysis of the employment returns to tertiary education, I rely on EU-LFS data (2005-2013) and focus on natives and first-generation immigrants originating from less economically-developed countries aged between 25 and 54. Given the aims of empirical analyses, immigrant status is thus defined considering the country of birth rather than nationality. Second-generation individuals of immigrant descent are included among natives as EULFS data do not contain information on parents' country of birth. Immigrants from EU-15 countries, EFTA, North America, Australia and Oceania are excluded, since they share peculiar characteristics and their employment outcomes are usually similar to those of natives. As far as the countries of residence, 10 Western European countries (Belgium, Denmark, Spain, France, Greece, Italy, the Netherlands, Norway, Sweden and the UK) have been selected. Ireland has been excluded because the sample size is too small for non-Western immigrants, thus the UK is the only representative of the Anglo-Saxon cluster. For the same reason, Finland has been excluded from the Continental cluster. Germany has also been excluded as, due to data limitations, immigrant status can only be defined through nationality. This poses severe problems for the cross-country comparison of the returns to education for immigrants, as German citizens would include foreign-born individuals who obtained their education in the country of origin. Portugal has been excluded from the Southern European cluster because of the very peculiar characteristics of its non-Western immigrant population, made up to a large extent by descendants of expatriates from former colonies. ${ }^{2}$

The dependent variable is a dummy taking value 1 if the respondent worked in the reference week, while the independent variable is a dummy taking value 1 if the respondent attained tertiary education. ${ }^{3}$ Educational attainment has been dichotomised because tertiary degrees are specifically exposed to problems of transferability of country-specific human capital and educational credentials, as well as for reasons of parsimony. ${ }^{4}$

The first step of the empirical analysis measures the employment returns to tertiary education by means of linear probability models implemented in each of the 10 selected countries separately by immigrant status and gender. The models are specified as follows:

$$
\begin{aligned}
& E(Y \mid X)=b_{0}+b_{1} \text { Tertiary }+X B+e_{i} \\
E(Y \mid X)= & b_{0}+b_{1} \text { Tertiary }+\Gamma(\text { Origin })+\Delta(Y S M)+ \\
+ & X B+e_{i}
\end{aligned}
$$

Models implemented in the sub-samples of natives (1) include a vector of coefficients $(X B)$ for the following control variables: six 5-year age dummies, a dummy taking value 1 if the respondent was in formal education in the previous four weeks, three dummies for the degree of urbanisation of the city of residence (densely, intermediate or thinly populated), region (NUTS-2) and year dummies and their interactions. ${ }^{5}$ The models for immigrants (2) include the same variables with the addition of two vectors of dummies ( $\Gamma($ Origin) and $\Delta(Y S M)$ ) for each area of origin (new Eastern European EU member states, other nonEU European countries, MENA, the rest of Africa, Asia and Latin America) and for years since migration in three categories $(1-5,6-10,>10) .{ }^{6}$ All models are estimated applying EU-LFS weights and with robust standard errors.

In the second step, empirical analyses test possible changes in the employment returns to tertiary education across economic conjunctures, focusing on immigrant and native men. Models are implemented with the same specifications as above but with the addition of an interaction term between the possession of a tertiary degree and period (2005-2007, 2008-2010 and 2011-2013).

\section{Results}

\subsection{Immigrant-Native Employment Gaps in Western Europe before and after the Economic Crisis}

Hypotheses on the cross-country differences in immigrants' employment returns to tertiary education (Table 1) rest on the existence of different models of immigrants' labour market incorporation. Thus, before presenting the results of the analysis of the employment returns to tertiary education, Figures 2 and 3 show adjusted immigrant-native employment gaps across the selected Western European countries for men and women,

\footnotetext{
2 In my analytical sample, $86 \%$ of non-Western immigrants originate from Sub-Saharan and Latin American countries.

${ }^{3}$ See Table A1 in Annex for sample sizes and descriptive statistics for the dependent and independent variables.

${ }^{4}$ It should be noted that such dichotomisation may hide possible non-linear effects of education on immigrants' employment chances. For instance, Luik et al. (2016) found higher employment rates in Sweden for non-EU immigrants with secondary education, compared to those with tertiary education.

${ }^{5}$ Region of residence is not available for the Netherlands in all years and for Denmark in 2005 and 2006, while the degree of urbanisation of the city of residence is not available for Norway between 2006 and 2009.

${ }^{6}$ Information on the years since migration is missing for many respondents in Spain (2005 and 2006) and especially in Denmark. However, model (2) specified without this variable provided very similar results for both countries.
} 

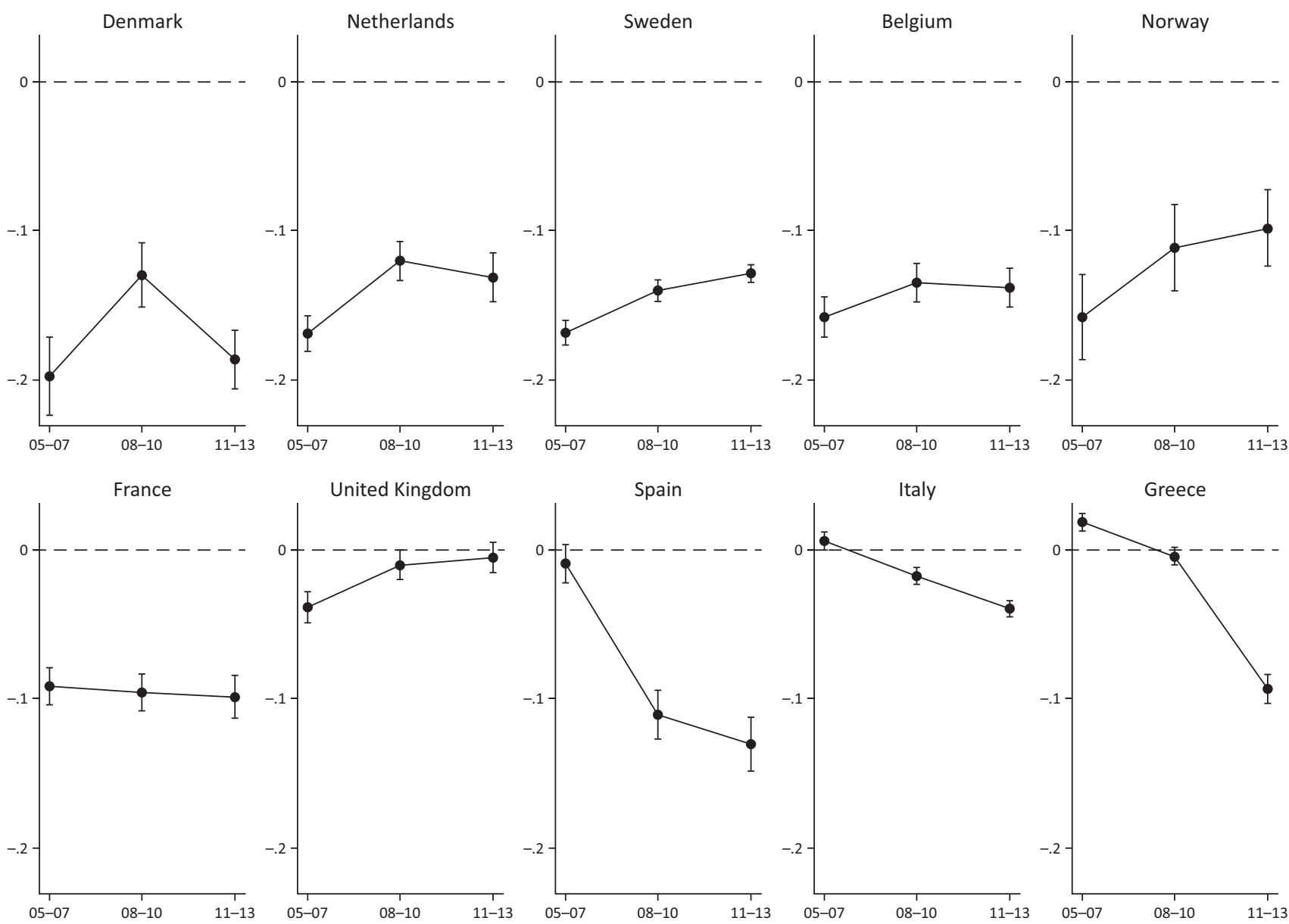

Figure 2. Immigrant-native employment probability gaps by country and period (MEN). Notes: Author's elaborations on EU-LFS data (2005-2013); points represent the beta coefficients (with 95\% c.i.) associated with the immigrant dummy (2005-2007) plus the interaction coefficients with period dummies (2008-2010, 2011-2013); countries are ordered by the decreasing size of the gap in the 2005-2007 period (see footnote 7 for additional details about the estimation).

respectively. Estimates are obtained using the same EULFS data and analytical samples described above. ${ }^{7}$

The empirical evidence is broadly consistent with the predictions of Figure 1. Starting with men, immigrant disadvantage in the pre-crisis period was on average much stronger in Continental Europe, and especially in Scandinavian countries, ranging from as much as a 20 p.p. lower employment probability in Denmark to approximately 10 p.p. in France. In the UK, the gap was significantly lower at approximately 4 p.p. At the other end, the gap was not statistically different from zero in Spain and was even marginally positive in Italy and Greece. After the onset of the crisis, however, a process of convergence occurred. In fact, while the gaps tend to remain stable or even slightly decline in all Continental countries and the UK, in Southern Europe, the gaps increase significantly, especially in Spain and Greece, where the share of immigrants who are employed in low-skilled jobs within small firms and hold fixed-term contracts is very high and where the crisis has been particularly severe. ${ }^{8}$

Among women, the cross-country pattern shows three remarkable differences. First, before the crisis, the intensity of the employment gaps was substantially higher throughout Continental Europe, ranging from approximately 25 p.p. in Belgium to approximately 16 p.p. in Norway. Second, the UK is now much more similar to the other Continental countries, with a gap of approximately 16 p.p. Third, while Southern European countries again show the lowest levels of immigrant disadvantage, the crisis has had substantially smaller negative effects among women compared to men, so the convergence across countries is also rather limited. This is likely due to the fact that manual jobs in construction and manufacturing, in which male immigrants are usually concen-

\footnotetext{
${ }^{7}$ Each figure plots interaction effects between immigrant status and period on employment probability derived from linear probability models controlling for 5-year age intervals, education (primary, low-secondary, tertiary), whether the respondent was in formal education in the previous month, the degree of urbanisation of the city of residence (densely, intermediate or thinly populated) and region (NUTS-2). All control variables are interacted with immigrant status. The models are implemented using EU-LFS weights and with robust standard errors.

${ }^{8}$ I estimate that in the selected time-window, non-Western immigrants have a 10 and 28 p.p. greater risk of holding a temporary job or work contract than natives in Greece and Spain, respectively. In the same countries, immigrants also have a 30 and 12 p.p. greater risk than natives of working in a firm with fewer than 11 employees.
} 

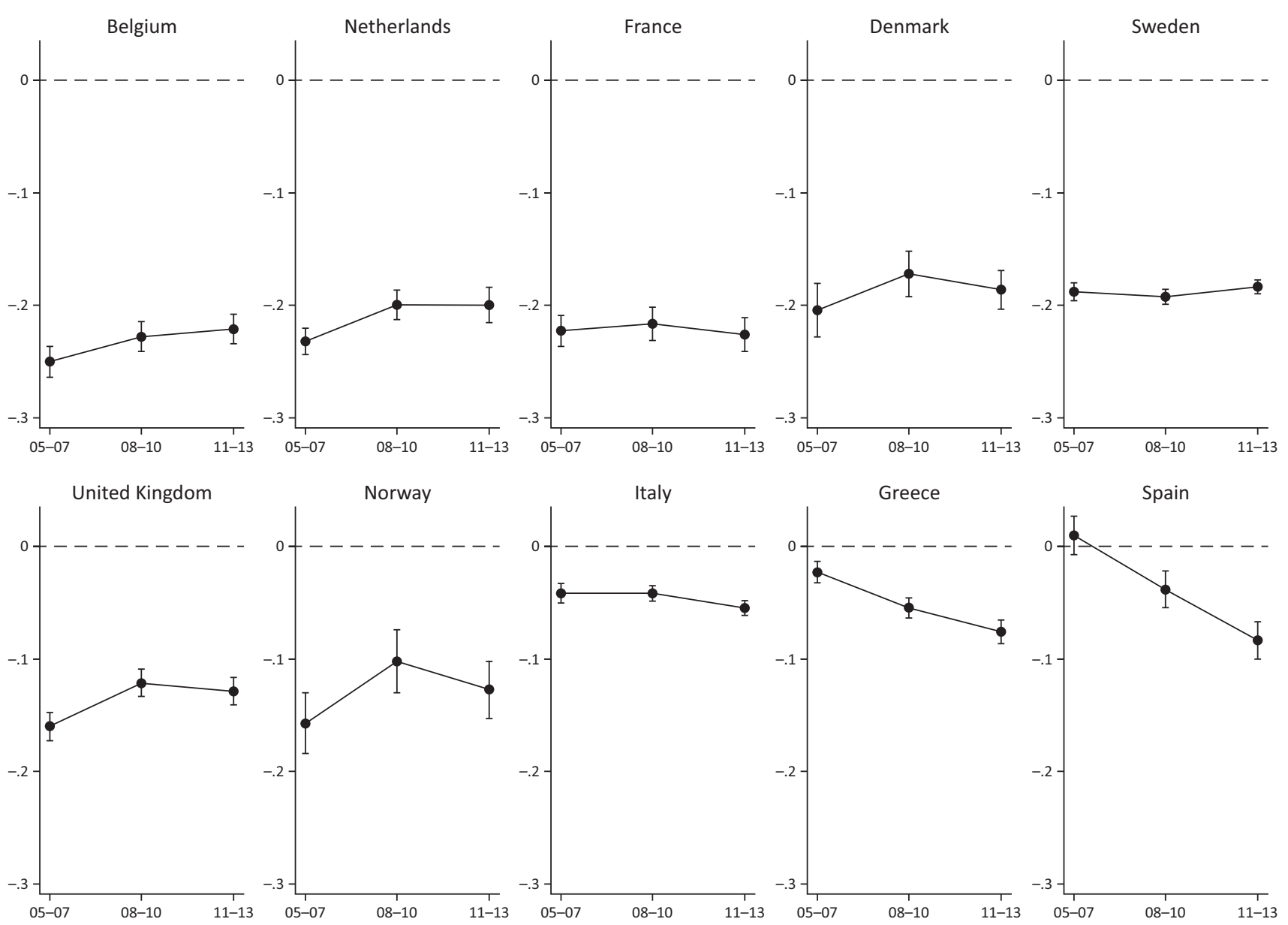

Figure 3. Immigrant-native employment probability gaps by country and period (WOMEN). Notes: Author's elaborations on EU-LFS data (2005-2013); points represent the beta coefficients (with 95\% c.i.) associated with the immigrant dummy (2005-2007) plus the interaction coefficients with period dummies (2008-2010, 2011-2013); countries are ordered by the decreasing size of the gap in the 2005-2007 period (see footnote 7 for additional details about the estimation).

trated, tend to be more sensitive to the economic cycle compared to jobs in personal services, in which most immigrant women work (Panichella, 2017).

\subsection{Employment Returns to Tertiary Education among Immigrants and Natives in Western Europe}

In Figures 4 and 5, employment returns to tertiary education are presented for immigrant men and women, respectively, together with the immigrant-native differences in the returns. ${ }^{9}$ Starting from men, the hypothesis that the returns should be higher for immigrants in Continental Europe is confirmed, where the possession of a tertiary degree is associated with a net increase of approximately 10 p.p. in employment probability. In Southern European countries, the returns are substantially lower, particularly in Greece, where they are not statistically different from zero. While the returns are higher for immigrants than natives in Continental Europe (approximately 4-5 p.p. higher employment probability in the Netherlands, Sweden and Belgium; the differences are statistically significant at the 0.000 level) or virtually identical (as in France, where the difference is not statistically significant), in Southern Europe, the returns are higher for natives (approximately 5 p.p. higher employment probability in Spain and Greece; the differences are statistically significant at the 0.000 level). The differences are not trivial given the high employment rates among prime-age men. The UK, consistent with the positioning of this country in the typology shown in Figure 1, occupies an intermediate position because the absolute returns among immigrants are in line with Continental countries, while the difference from the natives is slightly negative (approximately 1.5 p.p.; the difference is statistically significant at the 0.000 level).

Figure 5 presents the results for women. As hypothesised, while the overall pattern is very similar to the one found among men, some important differences need to be underlined. First, absolute returns are higher for immigrant women compared to immigrant men in all countries, but only marginally so in Italy and Greece. In fact, in Spain, the returns are slightly lower for immigrant

\footnotetext{
${ }^{9}$ Full tables are available upon request.
} 


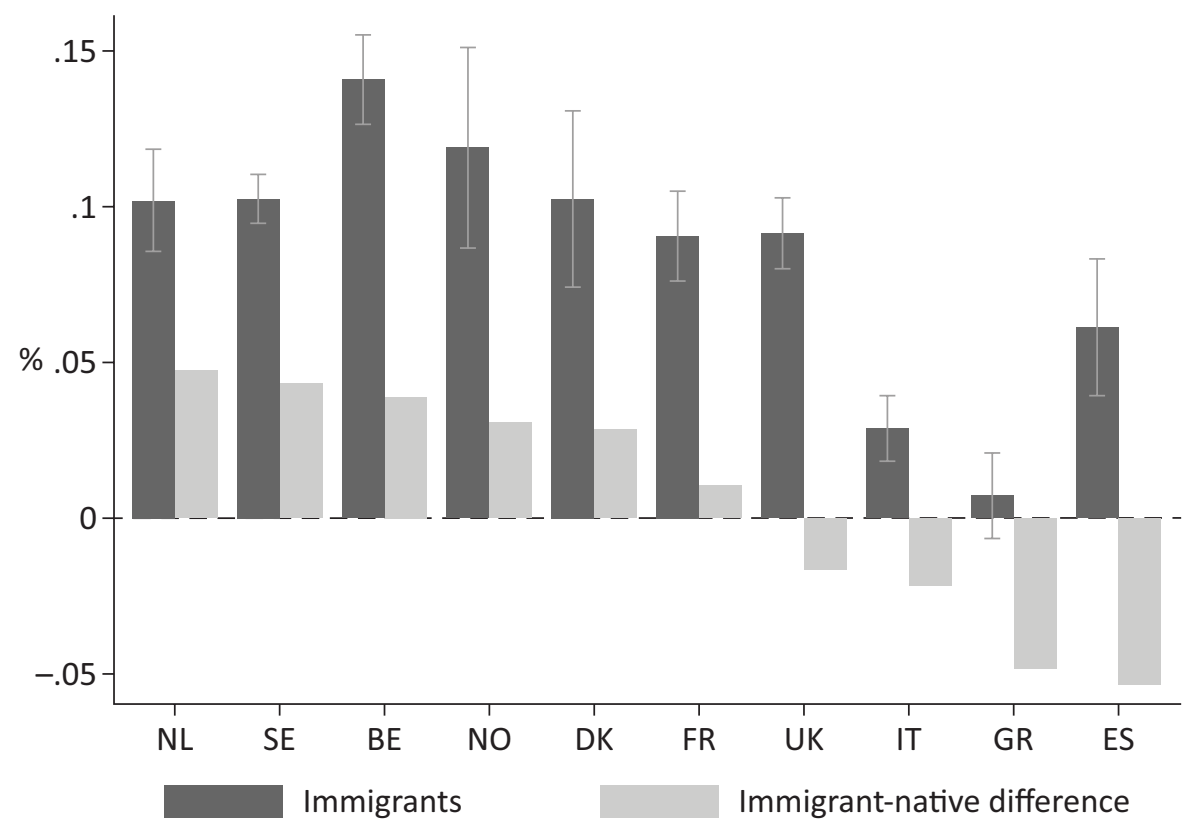

Figure 4. Employment returns to tertiary education among immigrants and differences with natives (MEN). Notes: Author's elaborations on EU-LFS data (2005-2013); dark bars represent beta coefficients (with 95\% c.i.) associated with the possession of a tertiary degree for the sub-samples of immigrants, based on equation (2), while grey bars represent differences from the same coefficients obtained for natives, based on equation (1).

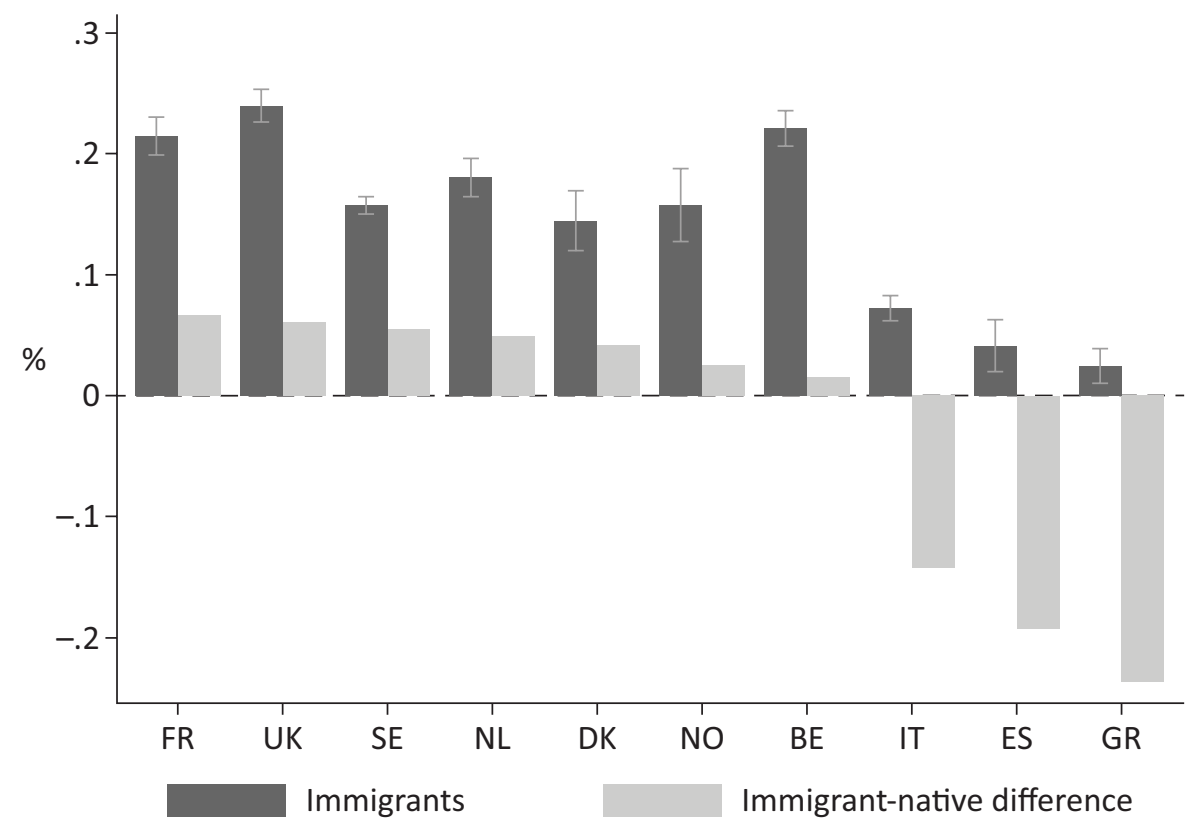

Figure 5. Employment returns to tertiary education among immigrants and differences with natives (WOMEN). Notes: Author's elaborations on EU-LFS data (2005-2013); dark bars represent beta coefficients (with 95\% c.i.) associated with the possession of a tertiary degree for the sub-samples of immigrants, based on equation (2), while grey bars represent differences from the same coefficients obtained for natives, based on equation (1).

women. This means that the differences between the Continental (UK included) and the Southern European models in the employment returns to tertiary education are larger among immigrant women (ranging between 10 and 15 p.p.), consistent with the hypothesis of Table 1. Second, in Southern Europe, the returns for immigrant women are substantially lower than those found for their native counterparts (approximately 20 p.p. in Spain and
Greece; the differences are statistically significant at the 0.000 level). As discussed in Section 2.2, this is likely the combined effect of the low employment rates among native women and the high employment rates of immigrant women originating from new Eastern European EU member, post-Soviet and Latin American countries in Southern Europe. 


\subsection{The Effect of the Crisis on the Cross-Country Pattern} of Employment Returns to Tertiary Education

In Figure 6, the results of the second step of the analysis, which focuses on how the returns have been affected by the crisis, are shown. As discussed in Section 2.2 and in light of the results shown in Figures 2 and 3, this is especially relevant for immigrant and native men. The results show that in the Netherlands, Belgium and Sweden, not much has taken place across economic conjunctures, so the returns are always higher among immigrants. In Norway and Denmark, the results for the immigrant populations, given their smaller sample sizes, are affected by high estimation uncertainty. However, in Denmark, as well as in France and Sweden, a significant increase in the returns for immigrants relative to natives after the onset of the crisis can be observed, consistent with the hypothesis that education becomes more salient for immigrants during negative economic conjunctures. In the
UK, employment returns to tertiary education were identical for immigrants and natives between 2005 and 2010, while in the last period, returns for immigrants reduced substantially. This may be explained by the increasing capability of the British labour market to employ immigrant workers, which may have come at the price of poorer job matches for immigrants. ${ }^{10}$

In Southern European countries, the employment returns to tertiary education among immigrants are found to increase. However, the returns also increase among natives after the onset of the crisis, as a response of their increasing difficulties in remaining employed (see Section 2.2). In fact, in Italy, the returns increase marginally among immigrants and slightly more so among natives such that, in the last period, the returns are significantly higher among natives. In Spain and Greece, countries where the immigrant-native employment gap increased the most (see Figure 2), the returns increased substantially for both immigrants and natives. Thus, although im-
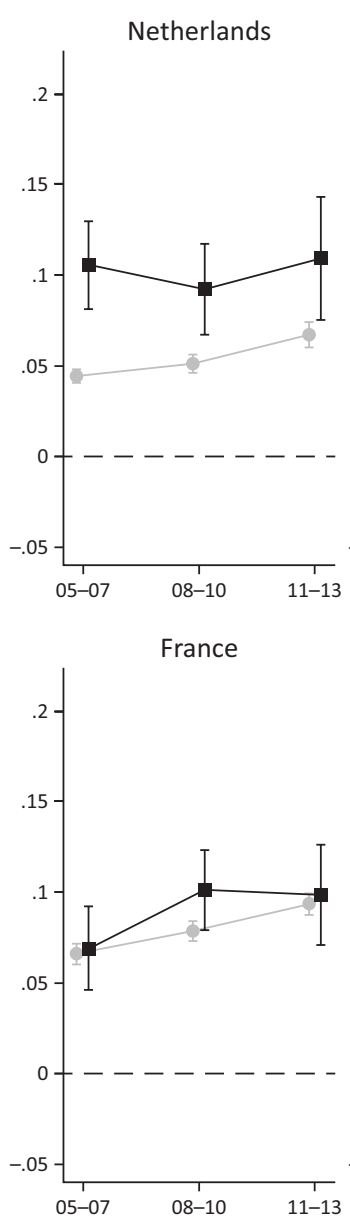

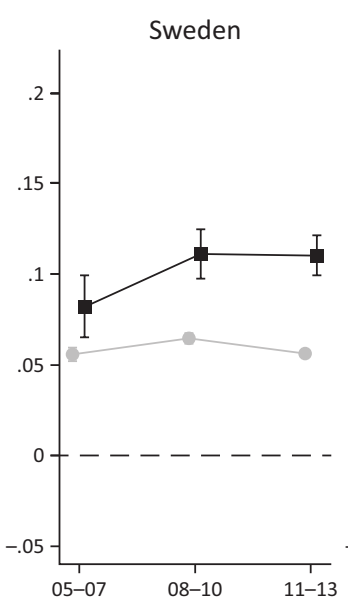

United Kingdom

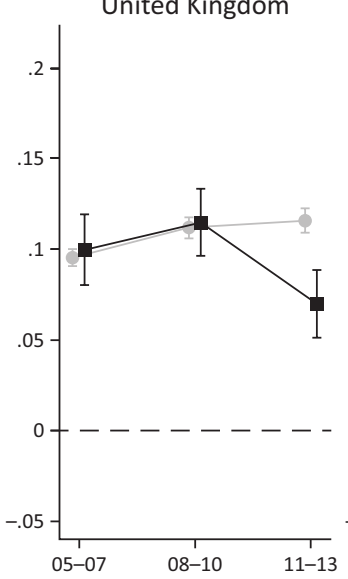

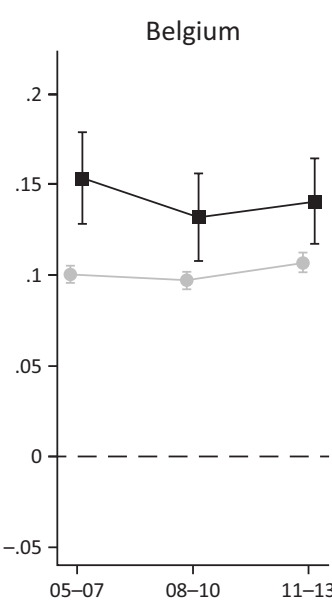

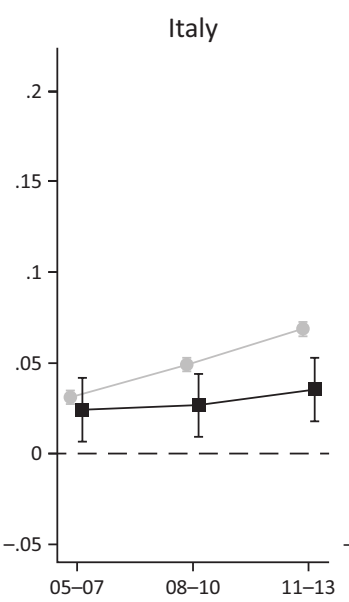

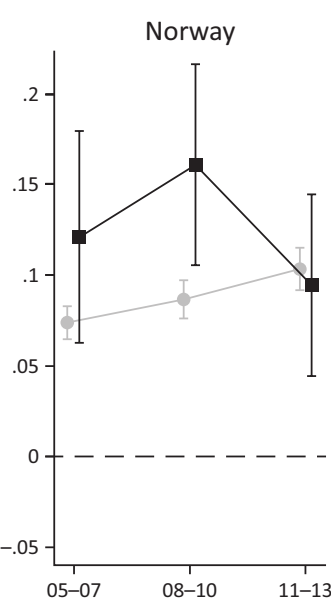
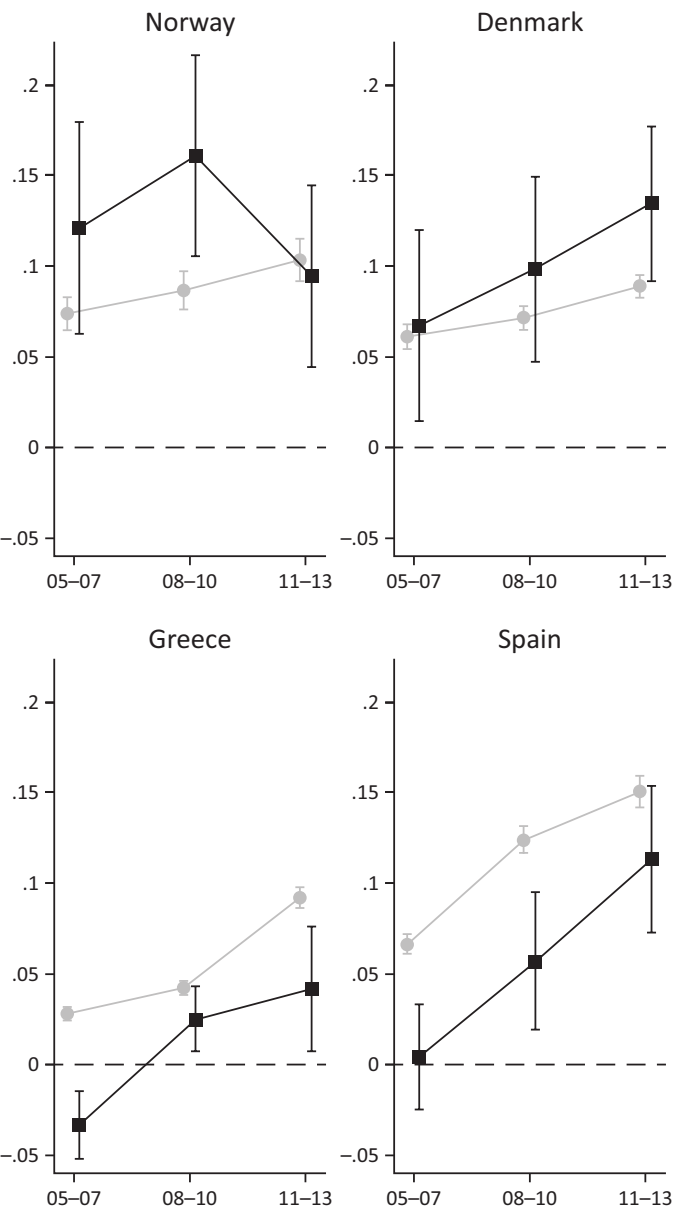

Figure 6. Employment returns to tertiary education among immigrant (dark lines) and native (grey lines) men. Notes: Author's elaborations on EU-LFS data (2005-2013); points represent the beta coefficients (with 95\% c.i.) associated with the possession of a tertiary degree (2005-2007) plus the interaction coefficients with period dummies (2008-2010, 2011-2013).

\footnotetext{
10 In the 2011-2013 period, no immigrant employment disadvantage among men was found (see Figure 2). However, the result may also be due to the sudden increase in the share of tertiary education among the sampled non-Western immigrants in the UK, which shifted between 2010 and 2011 from $35 \%$ to $47 \%$.
} 
migrants were hit much more heavily, their returns to tertiary education remain lower than those found for natives even after the crisis.

\section{Conclusion and Discussion}

This article argued and empirically showed that different models of immigrants' labour market incorporation contribute to cross-country differences in the employment returns to tertiary education in Western Europe. In Continental Europe, the immigrant employment disadvantage tends to be much larger than in the UK and Southern Europe. Apart from the different composition of the immigrant populations by area of origin and other migratory characteristics, I argued that the generosity of the welfare system for the unemployed and the labour demand bias towards high-skilled jobs are likely to play the most important role. In such a setting, higher educational attainment is likely to have a strong pay off for immigrants' employment probability, possibly offsetting the well-known problems of transferability of human capital and educational credentials acquired in the origin country. That is, I have hypothesised that tertiary education should matter more for immigrants' employment probability in Continental European countries and that returns to education could be higher for immigrants compared to natives in these countries. On the contrary, in Southern Europe, the very small immigrant employment disadvantage fostered by the high demand for low-skilled jobs, at least before the recent economic crisis, should make education less relevant for immigrants' employment chances above and beyond the limited transferability of human capital and credentials. In the UK, the returns for immigrants could be as high as in other Continental European countries given the similar characteristics of the labour demand, but their returns should not be higher compared to those of natives, given that the very selective immigration policy favouring the entry of highly-educated workers limits the immigrant employment disadvantage. The empirical results are consistent with these expectations, with larger cross-country differences found among women, although the substantially higher incidence of immigrants from predominantly Muslim countries in Continental Europe is likely a confounding factor.

Western European models of immigrants' labour market incorporation have been partly reshaped, however, following the Great Recession. Empirical evidence shows that while immigrant-native employment gaps remained unchanged or even decreased in all other countries, in Southern Europe, the immigrant disadvantage increased substantially, especially among men. Thus, one could have expected a convergence between the selected European countries regarding immigrant men's employment returns to tertiary education. The results show that the latter did increase in Southern European countries since the onset of the crisis, although at a different rate. In fact, in the 2011-2013 period, the abso- lute "employment premium" of a tertiary degree for immigrants in Spain is as high as in Continental countries. However, the returns to education also increased for native men in these countries as a response to their increasing difficulties in remaining employed. Thus, due to the crisis, non-Western immigrants in Southern European countries experience what could be defined as a "double penalty": not only is their employment gap with natives as high as in Continental countries after the crisis, but they also receive lower returns to tertiary education than their native counterparts. This is especially true in Italy and Greece, where the absolute returns to tertiary education for immigrants remain half of those of immigrants in Continental Europe, even after the crisis. This result is consistent with the very poor job matches for nonWestern immigrants in these countries, whose levels of segregation in the secondary segment of low- and unskilled jobs before the crisis were the highest in Western Europe (Panichella, 2017), irrespective of education and other individual characteristics (Fellini \& Guetto, 2018).

\section{Acknowledgements}

This research and this thematic issue have been supported by funding from the European Commission (Grant number H2020 649255). The author thanks Emilio Reyneri for reading and providing comments on preliminary versions of the article.

\section{Conflict of Interests}

The author declares no conflict of interests.

\section{References}

Brodmann, S., \& Polavieja, J. G. (2011). Immigrants in Denmark: Access to employment, class attainment and earnings in a high-skilled economy. International Migration, 49(1), 58-90.

Causa, O., \& Jean, S. (2007). Integration of immigrants in OECD countries: Do policies matter? (Working Paper no. 564). Paris: OECD Publishing. http:// dx.doi.org/10.1787/162367775052

Chiswick, B. R. (1978). The effect of Americanization on the earnings of foreign born men. Journal of Political Economy, 86(5), 897-922.

Chiswick, B. R., \& Miller, W. P. (2009). The international transferability of immigrants' human capital. Economics of Education Review, 28(2), 162-169.

Eurostat. (2013). European Union labour force survey (years 2005-2013). Eurostat. Retrieved from ec.europa.eu/eurostat/web/microdata/europeanunion-labour-force-survey

Fellini, I. (2017). Immigrants' labour market outcomes in Italy and Spain: Has the Southern European model disrupted during the crisis? Migration Studies, 6(1), 1-26. https://doi.org/10.1093/migration/mnx029

Fellini, I., Ferro, A., \& Fullin, G. (2007). Recruitment pro- 
cesses and labour mobility: The construction industry in Europe. Work, Employment and Society, 21(2), 277-298.

Fellini, I., \& Guetto, R. (2018). A “U-shaped" pattern of immigrants' occupational careers? A comparative analysis of Italy, Spain, and France. International Migration Review, 2018(Abril), 1-33. https://doi.org/ 10.1177/0197918318767931

Friedberg, R. M. (2000). You can't take it with you? Immigrant assimilation and the portability of human capital. Journal of Labor Economics, 18(2), 221-251.

Gorodzeisky, A., \& Semyonov, M. (2017). Labor force participation, unemployment and occupational attainment among immigrants in West European countries. PLOS ONE, 12(5), e0176856. https://doi.org/ 10.1371/journal.pone.0176856

Guetto, R., \& Fellini, I. (2017). Immigrant women's employment patterns: Disentangling the effects of ethnic origin, religious affiliation and religiosity. Rassegna Italiana di Sociologia, LVIII(4), 861-894.

Guzi, M., Kahanec, M., \& Kureková, L. M. (2015a). What explains immigrant-native gaps in european labor markets: The role of institutions (IZA Discussion Paper no. 8847). Bonn: IZA.

Guzi, M., Kahanec, M., \& Kureková, L. M. (2015b). How immigration grease is affected by economic, institutional and policy contexts: Evidence from EU labor markets (IZA Discussion Paper no. 9108). Bonn: IZA.

Hansen, J., \& Lofstrom, M. (2009). The dynamics of immigrant welfare and labor market behavior. Journal of Population Economics, 22(4), 941-970.

Hardill, I., \& Macdonald, S. (2000). Skilled international migration: The experience of nurses in the UK. Regional Studies, 34(7), 681-692.

Heath, A., \& Cheung, Y. (2007). Unequal chances. Ethnic minorities in Western labour markets. Oxford: Oxford University Press.

Heath, A., \& Martin, J. (2013). Can religious affiliation explain 'ethnic' inequalities in the labour market? Ethnic and Racial Studies, 36(6), 1005-1027.

Huber, P. (2015). What institutions help immigrants Integrate? (WWWforEurope Working Paper no. 77). Vienna: WWWforEurope. Retrieved from www.for europe.eu/fileadmin/documents/pdf/Workingpapers /WWWforEurope_WPS_no077_MS18.pdf

Kanas, A., \& Van Tubergen, F. (2009). The impact of origin and host country schooling on the economic performance of immigrants. Social Forces, 88(2), 893-916.

Kogan, I. (2006). Labor markets and economic incorporation among recent immigrants in Europe. Social Forces, 85(2), 697-721.

Kogan, I. (2007). Working through barriers. Host country institutions and immigrant labour market performance in Europe. Dodrecht: Springer.

Koopmans, R. (2016). Does assimilation work? Sociocultural determinants of labour market participation of European Muslims. Journal of Ethnic and Migration Studies, 42(2), 197-216.
Lancee, B. (2016). The negative side effects of vocational education: A cross-national analysis of the relative unemployment risk of young non-Western immigrants in Europe. American Behavioral Scientist, 60(5/6), 659-679.

Lancee, B., \& Bol, T. (2017). The transferability of skills and degrees: Why the place of education affects immigrant earnings. Social Forces, 96(2), 691-716.

Luik, M.-A., Emilsson, H., \& Bevelander, P. (2016). Explaining the male native-immigrant employment gap in Sweden: The role of human capital and migrant categories (IZA Discussion Paper no. 9943). Bonn: IZA.

Madsen, P. K. (2006). How can it possibly fly? The paradox of a dynamic labour market in a Scandinavian welfare state. In J. A. Campbell, J. A. Hall, \& O. K. Pedersen (Eds.), National identity and the varieties of capitalism: The Danish experience (pp. 321-255). Montreal: McGill-Queen's University Press.

Markaki, Y. (2014). Do labour market conditions shape immigrant-native gaps in employment outcomes? A comparison of 19 European countries (ISER Working Papers Series no. 2014-41). Essex: Institute for Social and Economic Research. Retrieved from www.iser. essex.ac.uk/research/publications/working-papers/ iser/2014-41.pdf

Nickell, S. (1997). Unemployment and labor market rigidities: Europe versus North America. Journal of Economic Perspectives, 11(3), 55-74.

OECD. (2009). The jobs crisis: What are the implications for employment and social policy? In OECD (Ed.), Employment outlook. Tackling the jobs crisis (pp. 17115). Paris: OECD.

OECD. (2017). Benefits and wages: Statistics. OECD. Retrieved from www.oecd.org/els/benefits-and-wagesstatistics.htm

Panichella, N. (2017). Economic crisis and occupational integration of recent immigrants in Western Europe. Acta Sociologica, 33(1), 64-85.

Reyneri, E. (1998). The role of the underground economy in irregular migration to Italy: Cause or effect? Journal of Ethnic and Migration Studies, 24(2), 313-331.

Reyneri, E. (2004). Immigrants in a segmented and often undeclared labour market. Journal of Modern Italian Studies, 9(1), 71-93.

Reyneri, E., \& Fullin, G. (2011a). Ethnic penalties in the transition to and from unemployment: A West European perspective. International Journal of Comparative Sociology, 52(4), 247-263.

Reyneri, E., \& Fullin, G. (2011b). Labour market penalties of new immigrants in new and old receiving West European countries. International Migration, 49(1), 31-57.

Sá, F. (2011). Does employment protection help immigrants? Evidence from European labor markets. Labour Economics, 18(5), 624-642.

Scherer, S., \& Reyneri, E. (2008). Com'è cresciuta l'occupazione femminile in Italia: Fattori strutturali e culturali a confronto, Stato e Mercato, 2008(2), 183-216. 
Sciortino, G. (2004). Immigration in a Mediterranean welfare state: The Italian experience in comparative perspective. Journal of Comparative Policy Analysis, 6(2), 111-129.

Siebert, H. (1997). Labor market rigidities: At the root of unemployment in Europe. Journal of Economic Perspectives, 11(4), 37-54.

Steiber, N., \& Haas, B. (2012). State of the art. Advances in explaining women's employment patterns. SocioEconomic Review, 10(2), 343-367.

Visser, J. (2015). Data base on institutional characteristics of trade unions, wage setting, state intervention and social pacts, 1960-2014 (version 5.0). Amsterdam: Amsterdam Institute for Advanced Labour Studies.

\section{About the Author}

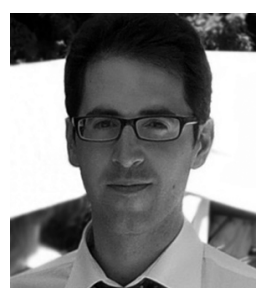

Raffaele Guetto obtained his Ph.D. in Sociology and Social Research from the University of Trento (2012), where he taught courses on education, social inequality and social policy. He is currently research fellow at the University of Milano-Bicocca. His research interests include social demography, social stratification and inequality, and immigration. His works have been published in European Sociological Review, Journal of Ethnic and Migration Studies, European Journal of Population and International Migration Review. 
Annex

Table A1. Sample sizes and proportions of tertiary educated and employed, by sex, immigrant status and country of residence. Analytical samples used for the analyses of Figures 4, 5 and 6.

\begin{tabular}{|c|c|c|c|c|}
\hline & \multicolumn{2}{|c|}{ Men } & \multicolumn{2}{|c|}{ Women } \\
\hline & Immigrants & Natives & Immigrants & Natives \\
\hline Belgium & 20,864 & 165,062 & 23,554 & 168,259 \\
\hline$\%$ tertiary & 26.56 & 33.61 & 27.90 & 40.73 \\
\hline$\%$ emp & 65.97 & 88.23 & 44.03 & 76.90 \\
\hline Denmark & 5,833 & 136,156 & 8,193 & 155,794 \\
\hline$\%$ tertiary & 30.52 & 33.90 & 30.21 & 44.04 \\
\hline$\%$ emp & 70.44 & 89.98 & 57.28 & 86.05 \\
\hline Spain & 18,746 & 284,749 & 21,401 & 293,961 \\
\hline$\%$ tertiary & 20.45 & 31.28 & 23.62 & 35.21 \\
\hline$\%$ emp & 74.56 & 83.01 & 60.12 & 61.71 \\
\hline France & 66,907 & 611,122 & 78,573 & 647,918 \\
\hline$\%$ tertiary & 27.37 & 28.73 & 26.33 & 33.96 \\
\hline$\%$ emp & 74.99 & 87.93 & 51.08 & 78.21 \\
\hline Greece & 45,984 & 455,239 & 45,284 & 470,700 \\
\hline$\%$ tertiary & 8.27 & 24.04 & 15.16 & 24.73 \\
\hline$\%$ emp & 84.41 & 85.38 & 53.36 & 58.53 \\
\hline Italy & 89,638 & $1,019,100$ & 107,813 & $1,057,260$ \\
\hline$\%$ tertiary & 7.49 & 13.23 & 13.30 & 16.83 \\
\hline$\%$ emp & 84.32 & 84.14 & 53.09 & 58.92 \\
\hline Netherlands & 19,661 & 246,675 & 25,164 & 254,568 \\
\hline \% tertiary & 24.11 & 34.95 & 23.24 & 32.16 \\
\hline$\%$ emp & 77.70 & 93.83 & 56.89 & 81.19 \\
\hline Norway & 4,240 & 60,453 & 5,113 & 59,810 \\
\hline$\%$ tertiary & 28.25 & 32.10 & 34.34 & 42.16 \\
\hline$\%$ emp & 76.26 & 90.60 & 66.07 & 85.02 \\
\hline Sweden & 55,284 & 467,992 & 67,696 & 471,437 \\
\hline$\%$ tertiary & 31.67 & 28.23 & 35.64 & 41.34 \\
\hline$\%$ emp & 72.62 & 90.18 & 62.28 & 87.15 \\
\hline UK & 20,277 & 155,039 & 23,174 & 172,737 \\
\hline$\%$ tertiary & 35.87 & 32.59 & 34.69 & 34.64 \\
\hline$\%$ emp & 83.77 & 87.31 & 58.62 & 76.85 \\
\hline
\end{tabular}

Notes: Author's elaborations on EU-LFS data (2005-2013), no weights applied; respondents aged 25 to 54; immigrants include firstgeneration immigrants originating from non-Western countries, while second-generation individuals of immigrant descent are included among natives. 